\title{
Homidium Chloride
}

National Cancer Institute

\section{Source}

National Cancer Institute. Homidium Chloride. NCI Thesaurus. Code C29022.

The chloride salt of ethidium (a fluorochrome), Ethidium Chloride intercalates within double-stranded nucleic acids, particularly DNA. In molecular biology, the bromide salt of ethidium is used to detect and visualize DNA after electrophoresis or in cytochemical preparations. In veterinary pharmacology, it is used as a trypanosomicide. Ethidium bromide and chloride are toxic substances and potent noncompetitive antagonists of the nicotinic acetylcholine receptor. ( $\mathrm{NClO4)}$ 